\title{
Challenges of Students Housing Provision in Malaysia
}

\section{Zubairu Abubakar Ghani ${ }^{1,2}$, Noralfishah Sulaiman ${ }^{2}$, Mohammed Ishaq Mohammed ${ }^{1}$}

\author{
${ }^{1}$ Abubakar Tafawa Balewa University \\ Tawafa Belewa Way, P. M. B. 0248, Bauchi, 740272, Nigeria \\ 2 Universiti Tun Hussein Onn Malaysia \\ 101 Parit Raja, Batu Pahat, Johor, 86400, Malaysia
}

\section{DOl: $10.22178 /$ pos. $64-3$}

JEL Classification: 018

Received 05.10.2020

Accepted 25.11.2020

Published online 30.11 .2020

Corresponding Author:

Zubairu Abubakar Ghani,

zubairughani@yahoo.co.uk

(C) 2020 The Authors. This article is licensed under a Creative Commons Attribution 4.0 License @ (1)
Abstract. The world population has been growing tremendously, which surged up the demand and enrolment in educational institutions to unimaginable level globally. Similarly, Malaysia has witnessed tremendous growth in higher education both in the order and establishment of new higher education institutions (HEls) to match up with the demand. However, there is no commensurate increase in the student housing facilities to match up with the growing enrolment and demand; hence, accommodate a certain proportion of the total students. The paper explored qualitative methodology data from in-depth expert interviews of selected public and private universities in Malaysia; discussed the problems of HEls student housing provision to four identified themes: student enrolment, government policy, funding and land issues as what exacerbated the issues. Therefore, challenges for student housing provision are enormous; hence HEls and Government cannot adequately respond and satisfy the demand unless private housing developers actively involved otherwise problems of student housing provision will continue to persist.

Keywords: higher education institution; student housing; student housing provision; student enrolment; higher education.

\section{INTRODUCTION}

The world population has been surging especially in the last three decades, and in particular, 100 million people were added to the world population every year between 2014 and 2017 where it stands at $7.2 \& 7.5$ billion respectively $[1,2]$. Authors [3] reported, looking at the world population growth, there is strong growth in student age population (16-39 years old) and postulated that by 2050 , the global student age population would reach 1.3 billion. Consequently, this implied a high rise in demand and enrolment in higher educational institutions (HEI). According to $[4,5]$ global students' number has drastically increased from 98 million in 2000 to 165 million in 2011 with an annual average of 6 million students and postulated student enrolment numbers are to increase by 32 million over the next ten years. Author [6] reported the number of HE students is anticipated to swell up to "263 mil- lion" globally by 2025. Similarly, [3] noted, between 2012 and 2017, the total global number of students in higher education institutions has increased by $11 \%$ to exceed 220 million. Indeed, these have shown higher education has been rapidly and steadily growing mainly in the last two decades where many young men were finishing high schools and seeking placement (applying) every year in higher education institutions (HEIs).

In Malaysia, the population has been steadily growing tremendously since 1957 . For instance, in 1957, the country's population was 7.3 million; the population doubled to the figures of 13.3 million and 27.0 million by 1980 and 2008, respectively [7]. According to Population Reference Bureau $[1,2]$, the population of Malaysia in 2015 and 2017 estimated at 30.8 \& 31.6 million respectively, this signifies the possibilities of simi- 
lar high increase in the demand for higher education (HE).

Malaysia is not different in the development and rapid growth of higher education institutions with over 671 HEIs [8] and recent year's enrolment into institutions of higher learning has increased tremendously. Equally, [9] said in the past decade, Malaysia has witnessed tremendous changes in the HE scenario, both in the demand and establishment of new HEIs in trying to match up with the order. With this development of the education sector, universities and colleges have been receiving an increasing number of students' enrolment each year. Furthermore, HEIs student population in Malaysia has been increasing steadily in the past two decades where enrolment stood at 664,402 in 2002 to a total of $1,325,699$ students in 2017. Similarly, it was reported, in Malaysia, there are 1.33 million student's enrolment in 2017 and expected to con- tinue increasing in years to come to hit 2.0 million by 2020 as expected $50 \%$ of the Malaysian youth age 18-25-year-olds would gain access to HEI.

Moreover, the Ministry of Education Malaysia reported student enrolment in public universities alone from 2014-2017 stood at 563,186; 540,$638 ; 532,049$ and 538,555 respectively and the total enrolment for both public and private universities in 2017 is $1,104,407$ [10]. Table 1 shows the steady growth of HEIs student population. This is a clear testimony that the student population has been increasing dramatically and will continue to grow in the future as more children are graduating from secondary schools. These entire scenarios are by implication, indicating a commensurate increase in pressure on the existing HEIs facilities and tremendous growth in student housing demand.

Table 1 - Higher education institutions students' enrolment from 2009-2017 in Malaysia

\begin{tabular}{|l|c|c|c|c|c|c|c|c|c|}
\hline Year & 2009 & 2010 & 2011 & 2012 & 2013 & 2014 & 2015 & 2016 & 2017 \\
\hline Enrol & $1,050,726$ & $1,134,134$ & $1,056,547$ & $1,114,589$ & $1,156,293$ & $1,167,077$ & $1,236,164$ & $1,346,858$ & $1,325,699$ \\
\hline
\end{tabular}

Source: Adopted from the [10]

Despite this growth of student population in HEIs, provisions of housing facilities are not proportional to the development of enrolment, especially in the last decade. Shortage in student housing in the HEIs could be attributed mainly to the high demand for HE and no corresponding increase in student housing to meet up the enrolment. Current trends of rapid enrolment changes and insufficient student housing development are impacting on students' daily life such as their housing comfort, convenience, safety and to some extent their academic achievement or performance [11]. Therefore, this paper intends to study the problems of HEIs student housing provision in Malaysia.

\section{Background}

Globally, there is progressive growth and demand for higher education following the unprecedented change in the student age demography. HE has been overgrowing in both developing and developed countries, especially in the last three decades, where many young people are graduating from secondary schools and gaining access to HEIs. Despite this growth, the provision of stu- dents' housing is not matching with the evolution, which led to the constraints and stretching the existing HEIs housing facilities. As [12] put it, the increase in the number of HEIs students; along with the growth in the size of HEIs have made the provision of student housing a challenge for all post-secondary education institutions. It was reported that many HEIs cities in the UK have sufficient student housing 'shortfalls'. In many HEIs, there is a significant or gross deficit in student housing that compelled many students to rent residential quarters outside their campuses.

Population and demand for HE is the main target for the decision for establishing HEI and other HEI supporting facilities such as student housing. The growing student demand for housing has a significant impact on the decision by any HEI to build student housing. Although, not all HEI students want to live in on-campus students' houses, but preferred to live out of core students' area for their privacy and freedom. To some extent' economic meltdown' of many countries, coupled with high growth in HEIs enrolment, increasingly making it difficult for HEIs to construct more housing units to sufficiently match with and pro- 
vide housing accommodation to all students. Therefore, the on-campus students housing remained grossly inadequate $[13,14,15]$. In line with this, it has been noticed that many HEIs with traditional housing facilities only accommodate small proportion about $20-30 \%$ of their total students' population $[16,17,18]$ therefore, majority of the students have to go to the private housing market.

Malaysia is not spared in the global trend of increase in student enrolment, in the past two decades, Malaysia has witnessed tremendous change in the HE scenario, one of the changes observed, is the acceleration towards mass education' to absorb the teeming population [19]. Further, [19] reported a total of 1.2-1.5 million students in public and private HEIs in Malaysia, in 2009 and the Ministry of Education Malaysia estimated the figure of the total enrolment of both public and private HEIs to be 2.0 million in 2020. This will increase the pressure on the HEIs existing facilities and derived more demands for learning spaces, residential facilities, recreational and other supporting facilities. Provisions of adequate and safe student housing are equally important. Still, the reality is on-campus housing is grossly inadequate; students have no other option than to seek for housing accommodation elsewhere close to their campuses where available.

The issue of student housing provision has been a challenge of long-standing but increasing concern for HEIs. The facts are, most campuses of public and private HEIs throughout the world and in Malaysia, continued to experience the unprecedented growth in enrolment. At the same time, the construction of on-campus housing options fell precipitously [19]. The inability of the HEIs to increase their housing capacity to match with the enrolled student population adequately has increased the demand for student housing in the private sector market, where students are compelled to search for private accommodation outside the campuses. Getting renting houses in the private market by students in HEI neighbourhoods or towns is problematic because in most cases secret places for renting are either not sufficient in supply or else the rent rate is high, not affordable to many students.

\section{Literature Review}

In recent years, student age population 16-29 years old who are finishing secondary schools has been increasing dramatically, which fuelled the demand for HE globally. The people of youth in any given country is the essential element formed the basis for decision making for establishing or expanding HEI. Authors [20] in confirmation reported that globally student enrolment in higher institutions has been increasing in recent times, and it is estimated that there has been 'about $160 \%$ increases in tertiary education globally'. Author [3] reported, in 2017, the total global number of students in higher education institutions has exceeded 220 million. Similarly, students are the main target for the establishment of any university and [21] attested that the increase in the number of university student cohorts fuelled the birth of new universities. Indeed, the global increase in youth population simultaneously increased the demand for $\mathrm{HE}$ globally and resulted to the extension of the exiting and establishment of new HEIs in the last three decades in both developed and developing nations $[22,23,24]$. This resulted in spurring up the enrolment, where many HEIs enrolled students more than their student housing carrying capacity, which becomes quite imperative and challenging for the HEIs towns to accommodate the teeming student population.

A global economic recession or rather crisis of 1997 \& 2012, has significantly affected HEIs student housing directly or indirectly in many ways and many countries. Author [25] observed, in the recent world economic recession that cut across nations, adversely affected all sectors, including education, particularly HEIs. Similarly, [26] presented that during the financial crisis, both statesupported and private colleges and universities felt the effects; many nation-states cut the amount of increased HEIs costs on non-academic core areas. In conformity to this, [27] argued, due to the restrictions placed on grants to HEIs, government spending did not cover the need for expanded non-core facilities. The economic meltdown of many countries led to budget cut for many sectors including education, coupled with high growth in HEIs enrolment, increasingly making it difficult for HEIs to construct more student housing units to sufficiently match with the enrolment (demand) and provide housing accommodation to students; therefore the oncampus students housing remained exceptionally inadequate $[9,14,28,29,30,31]$. Therefore, 
HEIs' tighter capital budgets, obviously turned them incapacitated to provide more student accommodation for the growing students' population and warrant them to focus on building classrooms, research facilities and offices and leaving students housing up to the private sector [14].

For years, providing students with housing in HEIs in many countries of the world has remained a significant challenge to HEIs. Shortage of student housing in HEIs could be attributed mainly to the high demand for HE, which increased dramatically in the past three decades, but with no corresponding expansion of student housing facilities to meet up the enrolment thus, straining the available housing in both public and private HEIs [20, 32]. Suppose such a scenario remains to be ignored. In that case, institutions could be entrapped in providing unfavourable academic environments which are quite unsupportive for students learning culture [33], where students' density in the housing facilities will be high thereby straining intellectual life comfort.

Malaysia is not different in the youth population surging, development and rapid growth of HEIs now with over 671 HEIs [8] and in recent years,' enrolment has increased tremendously. Equally, it has been observed, in the last decade, Malaysia has witnessed tremendous changes in the $\mathrm{HE}$ scenario, both in the demand and establishment of new HEIs to match up with the order. However, this increased number of HEIs, universities and colleges have been receiving an increasing number of students' enrolment each year. Furthermore, HEIs student population in Malaysia has been increasing steadily in the last two decades where the "enrolment stood at 664,402 in 2002 to a total of 1,134,134 students in 2010. More so, the Ministry of Education Malaysia reported HEIs student enrolment in 2017 at 1.8 million students [10]. This is because the demand and student population has been dramatically increasing and will continue to grow in the future as more children graduate from high schools and expect $50 \%$ or more of the Malaysian youth would gain access to HEI.

As it has been observed, despite this growth of students' population in HEIs, provisions of housing facilities are not proportional to the development of enrolment, especially in the last two decades. The facts are, most campuses of public and private HEIs in Malaysia will continue to have to experience the unprecedented growth in enrolment. At the same time, the construction of on-campus housing options fell precipitously [19]. Many studies noticed and reported HEIs in many countries to have insufficient student housing and most of the HEIs with traditional housing facilities only accommodate $20-30 \%$ of their total students' population. Therefore, the majority of the students are housed in the private housing market. Authors [14] spotted, incongruent growth in students' enrolment and housing facilities, necessitated many students to seek alternative accommodation option in the private housing rental market.

Similarly, researchers [34] observed this shortage of students housing and reported; universities maintained a few traditional hall types of accommodation for a few students. Then the majority had to go into the private rented market. Authors [38] summarised the situation of HEIs students housing shortfalls by the fact that the 'student population increase, has in general, run ahead of the ability of HEIs to accommodate them and has led to a growing reliance on the private rented sector'.

Being many of HEIs students are living in offcampus private rented houses, in many cases are at a disadvantage, because they find it difficult to get housing accommodation in the HEIs' neighbourhoods where the renting places are not sufficient in supply or cost-cap.

Some scholars have reported this circumstance; most off-campus student houses provided by the private rental market are either scarce, not purposely built students houses or somewhat lacked sufficient requisite facilities [13, 35].

Author [24] found that $70 \%$ of private hostels in university neighbourhood are being converted from family residential houses to hostels thus $[16,36]$ conclude, living off-campus students are necessitated to live in family housing like 'apartment, studio flats, condominium and terrace house'.

These proved that as students flew into the HEI neighbourhood for housing, any available housing with either substandard or else unavailable requisite facilities and services will be used which will not render the house to fulfil the function of modern student housing hence, there is no readily available purposely build student housing.

Another essential problem for student housing provision in HEIs island where many HEIs are faced with land constraints while others with 
available land for housing development will offer an opportunity for future student house expansion.

Old HEIs and HEIs that are located in highly dense populated towns would likely have no space for new student housing, possibly all land had been developed, and expansion will not be feasible unless some old buildings give way for further development. Many HEIs have been expanding as demand for HE and enrolment keep on increasing, additional classrooms, laboratories, lecture theatres, workshops, offices, student housing, etc. are needed and are competing for space to match with the current demands and growth. According to [29] typically, the available land for new development that HEI has is limited or not existing and building new dorms is not feasible. Conversely, in the highly densely HEI towns land for further development is scarce unless old buildings will be purchase and demolish for new construction of student housing. Indeed, the cost of such a product is usually prohibitive to especially HEIs $[15,37,38]$.

In some cases, land matters such as land laws and regulations may be cumbersome that causes delay in housing development and increase the cost of housing construction. Accordingly, the author [39] noticed technical requirements for land matters, planning, and building plan approval compliance translates into additional fees, and it also creates bureaucratic delays in the approval process. Similarly, the author [40] observed, the complexity of housing development in Malaysia, is due to mandatory compliances with various lands, planning and housing laws that are not all wholly synchronised and integrated. However, land matters sometimes tend to be more stringent and punitive, ostensibly to rein in the housing development as the laws and regulations continued to, instead of being facilitative to housing developments.

Governments of many countries have developed various housing policies to cater to their housing problems. Still, in most cases, governments are silent, and there is no government policy statement on student housing. Housing policies of many countries underscored student housing and not yet declare a policy on the responsibility to house the increasing student numbers, which left to be dealt with by individual HEI. According to [27] in a study in the USA reported there had been few government statements on the responsibility to the housing increasing students' popu- lation; it has been viewed as the responsibility of individual institution which instigated student housing problems to have persisted. This responsibility of individual institutions' will not be fulfilled as they were inadequately funded to respond to rapid increases in student populations.

\section{Methodology}

The paper is part of a large-scale study of HEIs students housing provision in Malaysia which is directed at providing an in-depth and interpretive understanding of student housing provision problems and paper explored qualitative study in generating data for the research. In this research, expert interview method was used to provide an opportunity for detailed investigation of people's personal opinions and experiences for an indepth understanding of the contextual issues within which research phenomena are established, and for detailed subject coverage [41, 42, $43,44]$.

Semi-structured interview question format was employed to give similar understanding to participants (respondents), and the type of data collection instrument is an in-depth expert interview of 'one-to-one' or 'in-person' that engaged individual participant for inquiring research phenomenon. We think that this method provides an opportunity for detailed investigation of each person's point of views, for an in-depth understanding of the circumstances within which the research phenomenon is situated [45].

Purposive sampling technique was employed where the participants were chosen because they have particular characteristics which will enable detailed exploration and understanding of the central theme as some scholars suggested [46, 47]. Development Officers of universities are chosen as our research participants based on their office responsibilities for providing and maintaining physical facilities visa-vie their knowledge on student housing provision. Three universities are selected for the study, two from public and one private to represent HEIs. We examined the transcripts to the four themes identified for coding and content analysis.

\section{RESULTS AND DISCUSSION}

Surging of youth population has tremendously pushed up the demand for HE, which invariably push-up the need for other HE related facilities 
such as classes, laboratories, libraries, students housing, and sporting facilities among others. It became clear that HEIs were unable to provide and expand their student housing in line with the rise in student enrolment. Many reasons make HEIs incapacitated in increasing their student's housing to correspond with the teaming population growth of students' enrolment. These were due to high students' enrolment, funding, government policy and land matters which formed the four themes identified.

\section{Students' enrolment}

Over the years, students housing in HEIs has become an intractable area of concern by the HEIs administrators as the enrolment out-numbered their housing facilities. The student population in recent year has been increasing and running consistently ahead of HEIs' available students housing facilities to accommodate the teeming students. HEIs provided student housing facilities in Malaysia generally have no vacancies, and each year the number of students enrolled exceeds the available HEIs student housing as in many countries [9, 36, 19, 48]. It was reported that HEIs Students population in Malaysia has been increasing steadily in the past decade and enrolment stood at 1.8 million student enrolments in 2017 [10].
In addition to the local population seeking enrolment in HEIs, the Malaysia Ministry of Higher Education has employed internationalisation as a primary focus in transforming higher education to be able to contest with other global higher education providers. For Malaysia to achieve its aim of becoming an international education hub by 2025 , targeted to enrol 250,000 international students in the country's HEIs $[48,49]$. The government set a goal of attracting 100,000 international students by 2010; estimates the foreign student population grow to 150,000 by 2015 , to 200,000 by 2020 and 250,000 by the turn of 2025 admission $[9,49,29,19,48]$. In the years of 2009 and 2017, Malaysian HEIs recorded 80,750 and 170,068 international student enrolments respectively, with a $7.6 \%$ annual increase toward attracting 250,000 international students to become an international education hub by 2025. Furthermore, the targeted 250,000 international students in addition to the local students' enrolment, will also aggravate students' housing problems. These are evidence for the possible increase in demand for HE that will spur up the enrolment, the demand for student housing in the future and turn exacerbate student housing problem in the HEIs. See Table 2 bellow justified the steady growth of international student enrolment in Malaysian HEIs.

Table 2 - International student enrolment in Malaysian higher education institutions (HEI) form 2008-2017

\begin{tabular}{|c|c|c|c|c|c|c|c|c|c|c|}
\hline Year & 2008 & 2009 & 2010 & 2011 & 2012 & 2013 & 2014 & 2015 & 2016 & 2017 \\
\hline No. & 69,174 & 80,750 & 86,919 & N/A & N/A & N/A & 135,502 & 151,979 & 172,886 & 170,068 \\
\hline
\end{tabular}

Source: Adopted from the [10]

Similarly, our interview respondents concurred on the significant growth in student population in their respective universities:

"Around 2012, if not mistaken, we have around 10-12,000 students so, now we have nearly 16,000 students and 20,000 students by the year 2017" (Participant No 1).

"In those days around 2000, the total student number was around 20-22,000, but now the total number of our student population is more than 25,000 including KL campus" (Participant No 2).

"I am not very sure, but our students now are around 1,200, and before now, maybe 2 or 3 years back, they are less than 1,000" (Participant No 3).
Therefore, these are clear testimonies that students' enrolment in Malaysian HEIs, like many other countries, has been increasing steadily as propositioned in many studies $[3,4,5,10,20]$.

\section{Funding}

As it has been observed, the global economic recession has substantially shaken HEIs student housing provision in many nations states, and Malaysia is not the exception, which adversely affected educational sector particularly HEIs [26, $25,27]$. This is being felt by limiting budget and restrictions placed on HEIs costs on nonacademic core areas like student housing. At the 
same time, government spending focuses more on expanding equipment and maintaining existing facilities.

"There is Malaysian Economic Development Plan No 10 (RMK10) then Government realised, they don't have enough money to build what so ever, they introduced Private Finance Initiatives (PFI) \& PPP projects. They construct hostels using the PFI model then rent to Government (university) and then to student... for the period of the concessionaire, normally is 20-25 years. After RMK 10 and now RMK11, there is no hostel being built by the Government using the traditional method or conventional way. All HEIs student hostels must be built through PPP" (Participant No 1).

"RMK 10 \& 11 no more money from the Government for new development. So, we have to find our initiatives to look for our own money for new development; now, government policy is no funding for new physical development only fund for equipment and maintenance of the existing facilities. Budget for new physical development is for young (new) universities like... but old Universities, no more budget for new physical development" (Participant No 2).

"Our accommodation, well, right now we rent all our accommodations from outsiders. You know, in private university we don't have a grant from the Government, is different from public universities. Our biggest problem is budget (funds) we cannot build students' accommodation, so we rent... we charged student base on the room type as we rent, so is costly" (Participant No 3).

When HEIs are stripped with insufficient funds to invest in non-core areas of their education business coupled with high construction costs, most HEIs will not be able to keep up with mounting housing demand. This confirmed many studies that stringent funds flow to HEIs impact on student housing provision [14, 28, 29, 30, 9, 31, 27]. It is important to note that with a budget cut or cash-stringent, constructing new student housing or take on a significant renovation of the old student house buildings can be cost-prohibitive to many HEIs [27]. However, the Government did not put a restriction on HEIs to make their initiatives on an extra budget or joint venture with private developers to construct new nonacademic core-areas. Indeed, many HEIs find it difficult or rather impossible to build new student housing thereby, on-campus student housing remained grossly inadequate, and many students have to depend on the private rental mar- ket for their housing accommodation [14]. Therefore, restrictions placed on grants to HEIs impacted negatively on the need for expanding student housing facilities.

\section{Government policy on student housing}

Governments of many countries including Malaysian has not yet declared a policy on student housing, most governments are silent, and there is no policy on student housing on the responsibility to house the increasing student numbers [27]. Policy developments underline the general trend viewing student housing as a matter to be dealt with by individual HEI. This responsibility will not possibly be fulfilled as they were not funded to respond to rapid increases in student populations.

Although most of the education policies are more comprehensive in respects of making HEIs more attractive and competitive with those world-class education providers, notably UK and USA, but generally were silent on student housing issues. Despite policy commitment of Government to boost up HE, little attention has been paid to the students housing consequences of expanded student numbers in HEIs.

Malaysian National Housing Policy, in a similar way, has not made a policy statement on students housing although the National Housing Policy goals is "to provide adequate, comfortable, quality and affordable housing to enhance the sustainability of the quality of life of the people". Even the three objectives of the policy did not specifically make any reference to student housing. However, the policy objective number two emphasises on "enhancing the capability and accessibility of the people to own or rent houses" [50]. Further to this, in the Malaysian Housing Development (Control and Licensing) ACT, 1966 (Act 118), student housing was not even mentioned as a matter of policy statement. As [27] presented, the perception is to leave the institutions to take care of their respective housing problems, and no other education stakeholders seem to be concerned and responsible; all these added to the confounding student housing provision problems in Malaysia.

However, these are the manifestations of our respondents about government policies on student housing in Malaysian HEIs: 
"Previously our Government has a lot of money, then we are using a conventional method of student housing provision where Government appoint a contractor to construct the hostels then university-run and maintain the hostels themselves. Now Government will not put their liability there... in the sense that, Government will not put themselves or their money in the construction. So, for student housing, we have to find our means. So, that is why Government allowed only $70 \%$ in-campus and $30 \%$ off-campus, the reason why Government insisted and allowed 70\%, is to develop a local economy with the 30\%" (Participant No 1).

"Previously, the government gave University some 'education funds'. The Government gave us some money which we built hostels; I thing nine colleges and government policy, say each university can cater for 20,000 students. Still, now our policy changed, no money from Government so, we are borrowing for hostel construction. Government policy now is a university in their initiatives should have funds for funding some projects" (Participant No 2).

On the private universities, it is indicated that government policy on student housing is silent as reported by a participant.

"Our own (private university) is different; Government is concerned with public universities. Private universities, we do our business, if accommodation is available, we give to students, others rent outside" (Participant No 3).

\section{Land Matters}

The land is the most critical resource for human habitation and all activities for any development. In many HEIs available land for expansion is limited or not existing, therefore, pose a problem for new growth. HEIs have been expanding as demand for HE and enrolment keep on increasing, additional classrooms, laboratories, lecture theatres, workshops, offices, etc. are needed and are competing for space to match with the current demands and growth. It was found that public universities were having vast land for future expansion when the need arises; on the contrary, the private university does not.

On the other hand, HEIs that are located in highly dense populated towns would likely to have no space for new student housing, possibly all land had been developed, and expansion will not be feasible unless some old buildings were demol- ished for the further development $[12,15,37$, 38].

For instance, University Heriot-Watt Malaysia located at the highly developed area of Wilayah Persekutuan, Putrajaya typically the available land for new development does not exist and building new student housing is not feasible.

"Our location is a problem because we are in the centre, and we cannot provide student accommodation on our campus. Our student accommodations are off-campus, not here, but within 15-20minute drive to the campus, we have to provide free-bus service to campus. So, we cannot provide, you see it is complicated to provide student accommodation" (Participant No 3).

However, due to insufficient land in HEIs, new construction may not be possible and frequently, to build new structures, old buildings have to be demolished or parking lots to be removed. Conversely, in the highly densely HEI towns land for further development is scarce unless old residential houses will be purchase and demolish for new construction of student housing. Indeed, the cost of such action is usually prohibitive to especially HEIs [12, 15, 37 \& 38].

On the other side, land acquisition law and laws are impediments to the provision of student housing where the process takes a long time for clearance, transfer, change the title and planning approval for development as $[39,40]$ reported. In respect to land issues, the respondents articulate:

"So, our problem is Land Matters because our land is not the Federal Government land yet is still under state land, so we cannot develop. Yeah! This is a very long process. Like our land here, since 2002 we bought this land, but the 'title' is still not ours, is still a state own, so we cannot lease, we cannot sublease, and we cannot develop. Because the land is state land and the federal don't want to involve in the matter. The state did not transfer the land to us because paying the premium to state is difficult, so we cannot develop the ground because of the case" (Participant No 1).

"Now we are discussing with Putrajaya Holding to building another one (student accommodation). Unfortunately, the site is not yet transferred to them; you see land issues are not easy; we cannot have it now" (Participant No 3).

However, another university is not affected by either of the above land problems because they have acquired a large expanse of land for future 
development which is still lying underutilised but are having trouble of conversion and changing title [39 \& 40].

"We have a lot of vacant lands (underutilise). So now we are planning to convert some of the lands to commercial. Now in Malaysia, if you want to convert land use from education to commercial, we have to change the land title to commercial. Otherwise, education is not commercial; you cannot do that. You see, changing the land title to commercial is very difficult, not easy" (Participant No 2).

\section{CONCLUSIONS}

The need for an effective and conducive student housing facility in HEIs cannot be overemphasised since students are expected to be in a good state of mind to excel in their academic endeavours which can be achieved by a sound student housing system. Students' population growth in HEIs coupled with the incongruent supply of student houses, low level of funding, government policy and land issues will undoubtedly continue to make on-campus student housing to be grossly inadequate and student housing provision problems to persist. It has been observed; many HEIs are faced with land constraints and tighter capital budgets which necessitated leaving student housing provision to the private sector. Therefore, there is need for collaboration between education stakeholders: Government, HEIs and private housing developers in student housing provision. It has become a significant concern and pertinent challenge to ensure private housing developers' participation in the provision of student housing is encourage, to supplements the inadequate students' residential infrastructure provided by the HEIs. Hence, HEIs/government alone cannot adequately satisfy the demand and the responsibility has been shifting solely to the private sector directly or indirectly and or formally or informally in the structure of student housing provision. Consequently, these are serious challenges not only to HEIs but to governments and the private housing developers to gear up for gauging student housing shortage for students' comfort, healthy living environment and achieving their education mission.

\section{Acknowledgement}

We sincerely acknowledged and appreciated for the encouragement and supports from Abubakar Tafawa Balewa University Bauchi, Nigeria for graduate fellowship and special thanks to Nigeria Tertiary Education Trust Fund (TET Fund) for fellowship grant that facilitated this research.

\section{REFERENCES}

1. Population Reference Bureau. (2016). 2016 World population data sheet. Retrieved from http://www.prb.org/pdf16/prb-wpds2016-web-2016.pdf

2. Population Reference Bureau. (2017). 2017 World population data sheet. Retrieved from http://www.prb.org/pdf17/2017_World_Population.pdf

3. Tostevin, P., \& Hyett, S. (2019). Global living. Retrieved from https://pdf.euro.savills.co.uk/globalresearch/report-global-living-2019.pdf

4. Jones Lang LaSalle. (2012). Student housing: a new global asset class. Retrieved from http://www.aninver.com/fotos/file/blog/Global-Student-Housing-Report-November-2012.pdf

5. Powley, T. (2013, June 3). How to invest in students property. Financial Times. Retrieved from https://www.ft.com/content/45dde256-cc39-11e2-9cf7-00144feab7de

6. Savills World Research. (2013, Summer). Spotlight European Student Housing. Retrieved from http://pdf.savills.com/documents/European_Student_Spotlight_2013.pdf

7. Abdullahi, B. C., \& Aziz, W. N. (2011). The role of private sector participation in achieving anticipated outcomes for low-income group: A comparative analysis of housing sector between Malaysia and Nigeria. African Journal of Business Management, 5(16), 6859-6890.

8. Jantan, M. (2011). SETARA: Malaysian Experience with Rating. Retrieved from https://www2.mqa.gov.my/aqaaiw/slides/PRESENTATIONS\%20- 
\%202012\%20AQAAIW\%20SEMINAR\%20AND\%20ROUNDTABLE\%20MEETING/Prof\%20Dr\% 20Muhamad\%20Jantan\%20-\%20Malaysia.pdf

9. Muslim, M. H., Karim, H. A., \& Abdullah, I. C. (2013). Well-Being of UiTM Shah Alam Students Living in Off-Campus Environment. Asian Journal of Environmental-Behaviour Studies, 4(13), 147-158.

10. Ministry of Education Malaysia. (2018). Quick Facts 2018. Retrieved from https://www.moe.gov.my/penerbitan/1587-quick-facts-2018-malaysia-educational-statistics$1 /$ file

11. Muslim, M. H., Karim, H. A., \& Abdullah, I. C. (2012). Challenges of Off-Campus Living Environment for Non-Resident Students' Well-Being in UiTM Shah Alam. Procedia - Social and Behavioral Sciences, 50, 875-883. doi: 10.1016/j.sbspro.2012.08.089

12. Spieler, A., Ong, S. E., \& Petrova, M. (2013). Demand for university student housing: An empirical analysis. Journal of Housing Research, 22(2), 141-164.

13. Hubbard, P. (2009). Geographies of Studentification and Purpose-Built Student Accommodation: Leading Separate Lives? Environment and Planning A, 41(8), 1903-1923. doi: 10.1068/a4149

14. Ghani, Z. A., Sulaiman, N., \& Mohammed, M. I. (2018). Student Housing a Resilient Housing Rental Market: Case of Federal Polytechnic Neighbourhood Bauchi, Nigeria. Path of Science, 4(3), 40084017. doi: $10.22178 /$ pos.32-7

15. Zaransky, M. H. (2006). Profit by investing in student housing: Cash in on the campus housing shortage. Chicago: Kalplan Publishing.

16. Muslim, M. H., Karim, H. A., \& Abdullah, I. C. (2012). Satisfaction of Students' Living Environment between On-Campus and Off-Campus Settings: A Conceptual Overview. Procedia - Social and Behavioral Sciences, 68, 601-614. doi: 10.1016/j.sbspro.2012.12.252

17. Kenna, T. (2011). Studentification in Ireland? Analysing the impact of students and student accommodation on Cork City. Irish Geography, 44(2-3), 191-213.

18. Alaka, I. N., Pat-Mbano, E. C. \& Ewulum, N. J. (2012). Contributions of Private Hostel Providers to Housing Needs of Imo State University Students, at Ugwuorji-Owerri Nigeria. Canadian Social Science, 8(2), 180-186. doi: 10.3968/j.css.1923669720120802.2755

19. Omar, D. B., Abdullah, F., Yusof, F., Hamdan, H., Nasrudin, N., \& Abdullah, I. C. (2011). The impacts of off-campus students on local neighbourhood in Malaysia. International Journal of Social, Behavioral, Educational, Economic, Business and Industrial Engineering, 5(10,) 1221-1227.

20. Nimako, S. G. \& Bondinuba, F. K. (2013). An empirical evaluation of student accommodation quality in higher education. European Journal of Business and Social Sciences, 1(12), 164-177.

21. Garmendia, M., Coronado, J. M., \& Urena, J. M. (2011). University Students Sharing Flats: When studentification Becomes Vertical. Urban Studies, 49(12), 2651-2668. doi: 10.1177/0042098011428176

22. Thomsen, J. (2008). Student Housing - Student homes? Aspects of student housing satisfaction (Doctoral thesis). Retrieved from https://brage.bibsys.no/xmlui/bitstream/handle/11250/231116/124643_FULLTEXT02.pdf?se quence $=1$ \&isAllowed $=\mathrm{y}$

23. Ghani, Z. A., \& Suleiman, N. (2017). Cash-Cow into the Purse of Malaysian Property Investors: Students Housing Investment. Path of Science, 3(8), 1013-1022. doi: 10.22178/pos.25-5

24. Onwong'a, M. (2012). An assessment of impacts of the growth of hostel accommodation on other land uses: a case study of Ngara west sub-location, Nairobi (Doctoral dissertation, University of Nairobi). Retrieved from http://erepository.uonbi.ac.ke/

25. Varghese, N. V. (Ed.). (2001). The Impact of the Economic Crisis on Higher Education in East Asia: Country Experiences. Paris: UNESCO and International Institute for Educational Planning. 
26. La Roche, R. C., Flanigan, M. A., \& Copeland Jr, P. K. (2010). Student Housing: Trends, Preferences and Needs. Contemporary Issues in Education Research, 3(10), 45-50.

27. Rugg, J., Rhodes, D., \& Jones, A. (2000). The nature and impact of student demand on housing markets. York: Joseph Rowntree Foundation.

28. Ghani, Z. A., \& Sulaiman, N. (2016). Theoretical underpinning for understanding student housing. Journal of Environment and Earth Sciences, 6(1), 163-176.

29. Ong, W. M. (2013). Students' Expectations and Perceptions of Service Quality Performance: University student advisors in Australia, Malaysia and Singapore (Doctoral dissertation, RMIT University). Retrieved from https://researchbank.rmit.edu.au/view/rmit:160441/Ong.pdf

30. Hammad, D. B., Musa, J. M., Rishi, A. G., \& Ayuba, I. I. (2013). Criteria for the selection of students' accommodation model in Nigeria tertiary institutions using analytic hierarchy process. Academic Research International, 4(5), 550-556.

31. Jaffar, A. R. (2012). Spatial analysis of studentification impacts on Kuala Lumpur local communities. N.d.: n. d.

32. Pace, M. E. (2007). Green luxury student housing: A real estate feasibility study (Master's thesis); Massachusetts Institute of Technology. Retrieved from https://dspace.mit.edu/bitstream/handle/1721.1/42033/228655941MIT.pdf?sequence=2\&isAllowed=y

33. Oginga, A. O. (2013). Undergraduate student accommodation in public universities: Challenges and opportunities case of the University of Nairobi. Retrieved from http://erepository.uonbi.ac.ke/handle/11295/78917

34. Stevenson, R., \& Askham, P. (2011). Purpose built student accommodation: changing face of student accommodation in Sheffield. Retrieved from http://shura.shu.ac.uk/11860/1/askham.pdf

35. Yusuff, O. S. (2011). Students Access to Housing: A Case of Lagos State University Students Nigeria. Journal of Sustainable Development, 4(2). doi: 10.5539/jsd.v4n2p107

36. Karpinski, M. (2015, March 13). Student accommodation in Malaysia. Retrieved from https://www.hotcoursesabroad.com/study-in-malaysia/student-accommodation/studentaccommodation-in-malaysia/

37. Smith, D. (2012). Studentification: the gentrification factory? Retrieved from https://southwarknotes.files.wordpress.com/2012/03/studentification-darren-smith.pdf

38. Rugg, J., Rhodes, D., \& Jones, A. (2002). Studying a Niche Market: UK Students and the Private Rented Sector. Housing Studies, 17(2), 289-303. doi: 10.1080/02673030220123234

39. Yam, M. (2013). Housing needs and aspirations: Challenges and changes in the industry. In Housing the Nation: Policies, Issues and Prospects (pp. 79-94). Retrieved from https://center4affordablehousing.org/wp-content/uploads/2014/10/Malaysia-Housing-theNation-Policies-Issues-and-Prospects.pdf

40. Siong, H. C. (2013). Land laws and their impact on housing. In Housing the Nation: Policies, Issues and Prospects (pp. 187-204). Retrieved from https://center4affordablehousing.org/wpcontent/uploads/2014/10/Malaysia-Housing-the-Nation-Policies-Issues-and-Prospects.pdf

41. Creswell, J. W. (2009). Research design: Qualitative, quantitative, and mixed methods approaches (3rd ed.). Los Angeles: Sage.

42. Ritchie, J. (2013). The Applications of Qualitative Methods to Social Research. In J. Ritchie, J. Lewis, C. Nicholls \& R. Ormston (Eds.), Qualitative research practice: a guide for social science students and researchers (pp. 24-46). Los Angeles: SAGE.

43. Naoum, S. G. (2007). Dissertation Research and Writing for Constrution students (2nd. ed.). London: Butterworth-Heinemann. 
44. Berg, B. L., \& Lune, H. (2017). Qualitative research methods for the social sciences (9th ed.). Boston: Pearson.

45. Lewis, J. (2013). Research Design. In J. Ritchie, J. Lewis, C. Nicholls \& R. Ormston (Eds.), Qualitative research practice: a guide for social science students and researchers (pp. 47-63). Los Angeles: SAGE.

46. Stake, R. E. (2010). Qualitative research: studying how things work. New York: The Guilford Press.

47. Bhattacherjee, A. (2012). Social science research: principles, methods, and practices (2nd ed.). Tampa: University of South Florida.

48. Aziz, A., Siong, H., Tin, L., M. Hamzah, M., \& Abdullah, D. (2011). Responding Towards Increasing International Student Enrolment in Malaysia. In International Higher Education Congress: New Trends \& Issues.

49. Ministry of Education Malaysia (2014). Quick Facts 2014: Malaysia Educational Statistics. Retrieved from http://www.moe.gov.my/index.php/en/media/penerbitan/terbitan/bukuinformasi/book/15/1?page=1

50. Ministry of Housing and Local Government. (n. d.). National Housing Policy. Retrieved from http://rehdainstitute.com/wp-content/uploads/2016/03/nhp.pdf 